\title{
Pengaruh latihan uchikomi osaekomi dan power lengan terhadap hasil osaekomi saat randori pada pejudo
}

\author{
Hoesana Dian Dewi Andalas *, Sugeng Purwanto \\ Fakultas Ilmu Keolahragaan Universitas Negeri Yogyakarta \\ Jalan Colombo No. 1, Karangmalang, Yogyakarta, Indonesia \\ *Corresponding Author. Email: hoesanadian@gmail.com
}

\begin{abstract}
Abstrak
Penelitian ini bertujuan untuk mengetahui: (1) perbedaan pengaruh antara metode uchikomi osaekomi berpasangan dan uchikomi bayangan terhadap hasil osaekomi saat randori, (2) perbedaan hasil osaekomi antara pejudo power lengan kuat dan power lengan lemah, (3) interaksi antara metode uchikomi osaekomi dan power lengan terhadap hasil osaekomi saat randori. Metode menggunakan eksperimen dengan rancangan faktorial 2 × 2. Populasi penelitian pejudo Daerah Istimewa Yogyakarta 44 pejudo. Sampel 24 pejudo dengan teknik purposive random sampling. Seluruh data diperoleh melalui tes power lengan dengan tes push up serta hasil osaekomi dengan randori selama empat menit. Teknik analisis data adalah ANAVA. Hasil penelitian menunjukkan: (1) ada perbedaan pengaruh yang signifikan antara latihan uchikomi dengan berpasangan dan uchikomi bayangan terhadap hasil osaekomi, (2) ada perbedaan yang signifikan hasil osaekomi antara pejudo yang memiliki power lengan kuat dan power lengan lemah, dan (3) ada interaksi antara metode uchikomi dan power lengan terhadap hasil osaekomi saat randori.
\end{abstract}

Kata Kunci: metode latihan uchikomi; power lengan; judo; hasil osaekomi.

\section{The effects of the exercise of uchikomi osaekomi and power arm on osaekomi results when randori judoka}

\section{Abstract}

This research aims to find out: (1) the difference between the methods of uchikomi osaekomi effects in pairs and uchikomi shadow on the results of the current osaekomi randori, (2) the difference between the results of osaekomi judoka arm which has high power and low power arm, and (3) the interaction between the method of uchikomi osaekomi and power arm on the results when below randori osaekomi. This research is the experimental method with $2 \times 2$ factorial design. The research population was Judoka Special Region of Yogyakarta. amounting to 44 Judoka. The Sampel of this research were 24 Judoka taken with random purposive sampling technique. All data of this research was obtained through tests and measurements of arm power by using the push-up test and the results of osaekomi Randori (contested) for four minutes. The data analysis technique used is the Variant Analysis (ANAVA). The results show that: (1) there is a significant difference between the exercise of uchikomi by twos and shadow uchikomi on osaekomi results, (2) there is a significant difference between the results of osaekomi judo Judoka who have power high arm and lower arm power, and (3) there is an interaction between the method of uchikomi and power arm on the results of osaekomi while randori.

Keywords: uchikomi exercise method; a power arm; judo; osaekomi results.

\section{PENDAHULUAN}

Perkembangan dunia olahraga yang semakin modern mempengaruhi perkembangan dan daya pikir insan olahraga sehingga dapat menunjang prestasi olahraga, salah satunya adalah dalam berlatih. tanpa latihan tidak mungkin tercapai prestasi secara optimal, saat berlatih pun harus dilakukan secara berulang-ulang, dengan kian hari kian menambah jumlah beban latihan sehingga tercapainya peningkatan hasil latihan. 
Judo merupakan olahraga kompetitif yang memberikan kesempatan untuk menunjukkan prestasi dan pembinaan pejudo, baik melalui latihan di klub-klub maupun perkumpulan lainnya. Oleh karena itu, perlu ada upaya atau usaha pengembangan melalui berbagai kegiatan pembinaan dalam meningkatkan prestasi pejudo. Tercapainya prestasi tinggi diperoleh melalui pembinaan yang tepat dan benar, serta usaha keras yang timbul dalam diri seorang pejudo. Selain itu seorang pejudo juga perlu ditunjang oleh berbagai faktor, antara lain kemampuan menguasai teknik, taktik, kondisi fisik yang prima, mental yang baik, kualitas pelatih, dan didukung juga sarana dan prasarana yang baik.

Judo olahraga yang berasal dari Negara Jepang. Diciptakan oleh Jigaro Kano pada tahun 1882. Judo terdiri dari dua suku kata, yaitu: Ju yang berarti lembut, dan Do yang berarti cara. Judo means the "gentle way" which reflects the philosophy of defeating an opponent with the least amount of effort or strength (Rodney, 2006, p.122) yang artinya Judo "cara lembut" yang mencerminkan filosofi mengalahkan lawan dengan sedikit usaha dan power. Jadi Judo adalah cara yang lembut, dimana dalam prakteknya Judo bukan untuk mencederai lawan tetapi hanya memanfaatkan tenaga yang digunakan oleh lawan (Noors, 2000, p.6).

Judo adalah seni, ilmu, dan olahraga yang merupakan sebuah bela diri dan alat pertahanan. Judo is an acyclic sport whose performance is complex to explain, because it may be determined by a combination of different physical abilities, as well as technical, tactical and psychological (Detanico, 2012, p.739), yang artinya Judo adalah olahraga yang kompleks, karena dapat ditentukan oleh kombinasi dari kemampuan fisik yang berbeda, serta teknis, taktis dan psikologis Praktek Judo untuk meningkatkan sportifitas, kerjasama, sosialisai, kontrol diri kepemimpinan dan kualitas karakter pejudo.

Dalam latihan Judo ada dua sebutan untuk pejudo yang melakukan teknik secara berpasangan. Tori adalah pejudo yang melakukan atau yang mengambil teknik, sedangkan $U k e$ adalah pejudo yang diambil teknik. Dalam olahraga Judo perlu dipelajari dasar-dasar Judo (khihon Judo). Dasar-dasar Judo meliputi penguasaan teknik dasar dan peraturan yang berlaku. Tanpa pengusaan dasar yang kuat, kita tidak akan menjiwai olahraga ini.

Menurut Noors (2000, p.43), secara garis besar, teknik dalam olahraga Judo dibagi atas tiga bagian besar. Yang masing-masing bagian ini dipecah lagi dalam bagian-bagian yang lebih kecil lagi. Ketiga bagian teknik utama itu adalah: (1) nage waza (teknik melempar/membanting) terdiri atas 2 bagian: tachi waza, yaitu teknik melempar sambil berdiri. sutemi waza, yaitu teknik melempar sambil menjatuhkan diri; (2) katame waza (teknik permainan bawah) katame waza (teknik permainan bawah), terdiri atas 3 bagian: osaekomi waza, yaitu teknik kuncian. shime waza, teknik cekikan. kansetsu waza, teknik patahan sendi; (3) atemi waza (teknik memukul dan menendang) terdiri 2 bagian: ude ate, yaitu menyerang dengan tangan. ashi ate, yaitu menyerang kaki. Tetapi di dalam latihan Randori dan pertandingan bebas (shiai), teknik atemi waza (teknik memukul/menendang) tidak diperbolehkan, karena dalam latihan randori dan pertandingan bebas (shiai) hanya boleh memakai teknik nage waza dan katame waza.

Dalam olahraga Judo, keberhasilan seorang pejudo dalam mencapai prestasi tinggi tidak akan tercapai tanpa proses latihan, dimana melalui program latihan yang sistematis, disiplin, dan motivasi dari atlet itu sendiri. Latihan yang dilaksanakan harus sistemis, di mana program latihan itu sendiri harus terukur, terstruktur, dan tercatat (Ghazali et al, 2019; Sukadiyanto, 2011, p.3).

Pengertian latihan (training) adalah aktivitas manusia yang menunjang terhadap pemenuhan kebutuhan fisiknya. Latihan adalah suatu proses yang sistematis dari program aktivitas gerak jasmani yang dilakukan dalam waktu relatif lama dan berulang-ulang, ditingkatkan secara progresif (bertahap) dan individual yang mengarah kepada ciri-ciri fungsi fisiologis dan psikologis manusia untuk mencapai sasaran yang telah ditentukan (Yudiana, 2009, p.2).

Prinsip latihan (training) menurut Irianto (2002, p.11) adalah suatu proses mempersiapkan organisme atlet secara sistematis untuk mencapai mutu prestasi maksimal dengan diberi beban fisik dan mental yang teratur, terarah, meningkat, dan berulang-ulang waktunya. Menurut Irianto (2004, p.105) "metode-metode latihan ditentukan oleh isi/materi latihan, karakteristik beban, sarana dan prasarana latihan serta disesuaikan dengan keadaan paedagogis dan fisiologis atau kebutuhankebutuhan kelompok penerima". Sesuai dengan kemampuan kondisi yang menentukan prestasi suatu cabang olahraga, maka kemampuan motorik yang sesuai akan dikembangkan melalui metode-metode latihan yang tepat. Metode latihan merupakan cara-cara yang terencana secara sistematis dan beroreintasi kepada tujuan. 
"Training is usually defined as systematic process of repetitive, progressive exercises, having the ultimate goal of improving athletic performance" (Bompa, 2009, p.125). Artinya bahwa latihan biasanya didefinisikan sebagai suatu proses sistematis yang dilakukan secara berulang-ulang, progresif, dan mempunyai tujuan untuk meningkatkan penampilan atlet.

Dari pengertian latihan di atas, dapat peneliti simpulkan bahan latihan penting bagi atlet untuk mencapai puncak prestasi, dengan adanya program latihan yang disusun dan di implementasikan secara kontinyu, maka atlet akan terbiasa beradaptasi serta meningkatkan kualitas fisik maupun psikis. Pada prinsipnya latihan merupakan suatu proses perubahan ke arah yang lebih baik, yaitu untuk meningkatkan: kualitas fisik, kemampuan fungsional peralatan tubuh, dan kualitas psikis anak latih. Dalam olahraga prestasi proses tersebut akan berhasil apabila ada kerjasama antara pelatih yang berpengalaman dan berpengetahuan dengan ilmu olahraga yang benar-benar menekuni bidang kepelatihan (Sukadiyanto, 2010, p.1).

Keberhasilan dalam proses latihan sangat tergantung dari kualitas yang dilaksanakan, karena proses latihan merupakan perpaduan kegiatan dari berbagai faktor pendukung. Menurut Sukadiyanto (2010, p.5) kualitas latihan ditentukan terutama oleh keadaan dan kemampuan pelatih serta olahragawan, keduanya harus memiliki kemampuan, kemauan, dan komitmen yang tinggi untuk meraih hasil yang baik.

Dalam olahraga Judo yang ada di DIY, masih kurangnya pejudo menerima bentuk-bentuk latihan sehingga pejudo kurang menguasai teknik yang berpengaruh pada penguasaan teknik dalam latihan randori untuk memperoleh nilai sempurna. Berdasarkan observasi dalam setiap pertandingan, teknik permainan bawah (katame waza) khususnya osaekomi mempunyai peranan dalam pencapaian suatu nilai sempurna (ippong). Sehingga dalam setiap pertandingan, saat bergumul di bawah atlet masih kurang menguasai teknik-teknik permaian bawah khususnya osaekomi. Dalam pengusaan teknik hanya teknik permainan atas (nage waza) yang selalu dilatihkan, sehingga atlet kurang menguasai teknik-teknik permaian bawah khususnya osaekomi.

Sehingga dalam setiap pertandingan, saat bergumul di bawah atlet masih kurang menguasai teknik-teknik permaian bawah khususnya osaekomi. Padahal di dalam olahraga Judo teknik-teknik yang diajarkan bukan hanya permainan atas (nage waza) tetapi juga ada teknik-teknik permainan bawah (katame waza) khususnya osaekomi waza. Padahal di dalam olahraga Judo teknik-teknik yang diajarkan bukan hanya permainan atas (nage waza) tetapi juga ada teknik-teknik permainan bawah (katame waza) khususnya osaekomi waza. Sehingga berpengaruh pada prestasi pejudo DIY baik di tingkat nasional maupun internasional, selain itu masih minimnya kompetisi/kejuaraan daerah menyebabkan kurangnya persaingan sehingga kurang memberi semangat atlet untuk berprestasi ditingkat yang lebih tinggi.

Dengan minimnya prestasi atlet judo di daerah Yogyakarta inilah maka peneliti bermaksud untuk memberikan metode latihan yang bisa juga dipadukan atau dikolaborasi dengan program yang dimiliki pelatih. Dengan memadukan atau berkolaborasi program latihan antara pelatih dan peneliti, maka diharapkan dapat meningkatkan teknik-teknik dalam latihan dan meningkatkan prestasi.

Di dalam latihan Judo ada istilah uchikomi. Jigoro Kano sebagai pencipta Judo telah menerapkan beberapa faktor yang harus dikuasai oleh setiap pejudo agar mampu mencapai prestasi yang tinggi yaitu satu bentuk latihan adalah dengan latihan uchikomi. Uchikomi (repetitive technical training) is a specific judo exercise that can be used to improve aerobic and anaerobic fitness (Franchini, 2014, p.2), yang artinya uchikomi (pelatihan teknis berulang) adalah latihan judo khusus yang dapat digunakan untuk meningkatkan kebugaran aerobik dan anaerobik. Uchikomi adalah latihan memasukan teknik atau membiasakan gerakan salah satu teknik yang dilakukan secara berulang-ulang. Judo is a combat sport characterized by high-intensity intermittent efforts yang artinya Judo adalah olahraga kontak fisik yang ditandai dengan intensitas tinggi dalam berlatih (Franchini, 2015). Selain itu diperlukan juga latihan yang baik dan teratur untuk mencapai hasil yang maksimal untuk menuju prestasi yang lebih baik. Bentuk latihan Uchikomi ini bisa digunakan untuk nage waza (teknik osaekomi) dan katame waza (teknik permainan bawah). Salah satu upaya agar pejudo mempunyai kualitas teknik andalan adalah dengan melakukan uchikomi/drill, dalam hal ini penguasaan teknik bertujuan untuk mendapatkan nilai sempurna (ippong). Karena itu seorang pejudo harus menguasai teknik andalan dengan sebaik mungkin.

Keberhasilan dalam melakukan teknik osaekomi dipengaruhi faktor pejudo itu sendiri, perbedaan kemampuan terutama terjadi karena kualitas fisik atau biomotor yang berbeda. Rahyubi 
(2012, p.209) menyatakan bahwa faktor-faktor yang mempengaruhi proses latihan keterampilan gerak adalah faktor internal dan faktor eksternal. Kondisi internal mencakup faktor-faktor yang terdapat pada individu, atau atribut lain yang membedakan pemain satu dengan pemain lainnya. Salah satu kondisi internal adalah kemampuan fisik, kemampuan fisik berhubungan dengan power yang akan mempengaruhi terhadap teknik osaekomi. Power adalah kekuatan otot yang bekerja dalam waktu singkat. Menurut Bompa yang dikutip oleh Fadil (2012, p.5), power adalah kemampuan otot untuk mengeluarkan kekuatan maksimal dalam waktu yang amat singkat, dengan demikian dapat dinyatakan bahwa power merupakan salah satu prasyarat dalam usaha pencapaian prestasi maksimal bagi pejudo dalam latihan teknik osaekomi.

Dalam penelitian ini uchikomi yang akan diterapkan adalah latihan uchikomi osaekomi shadow dan latihan uchikomi berpasangan. Latihan uchikomi adalah latihan memasukan teknik atau membiasakan gerakan salah satu tehnik yang dilakukan secara berulang-ulang. Melihat dari cara pelaksanaan uchikomi yang dilakukan secara berulang-ulang hal ini memiliki kesamaan dengan metode latihan drill. Latihan uchikomi banyak variasinya, contohnya latihan uchikomi bayangan (shadow), latihan uchikomi karet ban dan uchikomi berpasangan. Latihan uchikomi dengan karet ban hanya dikhususkan untuk teknik-teknik permainan atas (nage waza), tetapi latihan uchikomi bayangan (shadow) dan latihan uchikomi berpasangan bisa diterapkan untuk teknik-teknik permainan atas (nage waza) atau teknik-teknik permainan bawah (katame waza).

Oleh karena itu, yang perlu ditingkatkan adalah bentuk-bentuk latihan yang lebih bervariasi terutama Uchikomi untuk latihan osaekomi. Salah satu bentuk latihan uchikomi yang dilakukan adalah uchikomi bayangan (shadow) osaekomi dan uchikomi berpasangan osaekomi. Uchikomi bayangan (shadow) osaekomi adalah latihan uchikomi individu, sedangkan uchikomi berpasangan osaekomi adalah latihan uchikomi yang dilakuan antara tori dan uke.

Latihan Uchikomi bayangan (shadow) osaekomi adalah latihan uchikomi individu dengan mengambil teknik, taktik, fisik pejudo, serta timing yang tepat untuk mengunci lawan. Bentuk latihan uchikomi shadow ini bisa membantu pejudo untuk belajar kecepatan, tehnik, fisik atlet, serta timing yang tepat untuk mengunci lawan. Dengan membayangkan melakukan pengambilan teknik maka pejudo dapat melakukan kecepatan dalam penguasaan teknik saat latihan uchikomi osaekomi. Latihan uchikomi bayangan (shadow) osaekomi memiliki beberapa fungsi seperti melatih kecepatan pada saat mengambil kuncian, hal ini sangat berguna bagi setiap pejudo karena pada saat latihan randori (latihan bertanding) kecepatan sangat berperan dalam pertandingan. Diharapkan dengan latihan ini dapat dihasilkan kecepatan dalam pengambilan suatu teknik.

Berikut keunggulan uchikomi bayangan (shadow) osaekomi: Bentuk latihan uchikomi shdow ini bisa membantu pejudo untuk belajar kecepatan, tehnik, fisik atlet, serta timing yang tepat untuk mengunci lawan. Dengan membayangkan melakukan pengambilan teknik maka pejudo dapat melakukan kecepatan dalam penguasaan teknik saat latihan uchikomi osaekomi. (1) Latihan uchikomi bayangan (shadow) osaekomi memiliki beberapa fungsi seperti melatih kecepatan; (2) Latihan uchikomi bayangan (shadow) osaekomi dapat dilakukan secara mandiri. Selain ada keungggulan, latihan uchikomi bayangan (shadow) osaekomi juga ada beberapa kelemahan. Berikut kelemahan uchikomi bayangan (shadow) osaekomi: (1) Uchikomi bayangan (shadow) osaekomi terlalu tergantung pada satu titik; (2) Uchikomi bayangan (shadow) osaekomi tidak membiasakan pejudo berhadapan langsung dengan individu lain sehingga mengalami perbedaan ketika pejudo dirandorikan atau dipertandingkan.

Latihan uchikomi lainnya adalah uchikomi berpasangan osaekomi, bisa membantu pejudo untuk belajar kekuatan dan kecepatan, tehnik, dan fisik atlet. Latihan uchikomi osaekomi yang berpasangan maksudnya tori melakukan uchikomi sambil mengambil teknik ke uke. Selain itu uchikomi berpasangan bisa diterapkan program variasi latihan baik repetisi serta kecepatan dalam melakukan uchikomi sehingga dapat meningkatkan hasil kuncian Diharapkan dengan latihan ini dapat dihasilkan kecepatan dan kekuatan dalam pengambilan suatu teknik.

Berikut keunggulan uchikomi osaekomi yang berpasangan: (1) Latihan uchikomi osaekomi yang berpasangan memiliki beberapa fungsi seperti membiasakan ketepatan atau timing pejudo pada saat randori; (2) uchikomi osaekomi yang berpasangan diterapkan ke dalam program variasi latihan baik repetisi serta kecepatan; (3) uchikomi osaekomi yang berpasangan juga dapat dilakukan dengan berganti pasangan, baik itu sesuai dengan berat badan, tinggi dan rendahnya pasangan sehingga pejudo pada saat randori atau bertanding akan terbiasa dengan ukuran baik lawan yang berukuran tinggi atau 
rendah. Selain ada keungggulan, latihan uchikomi osaekomi yang berpasangan juga ada beberapa kelemahan. Berikut kelemahan uchikomi osaekomi yang berpasangan: (1) uchikomi osaekomi yang berpasangan memudahkan pejudo, terkadang pasangan pejudo pada saat uchikomi uke (lawan yang dikunci) membantu tori (yang mengunci) dalam melakukan uchikomi; (2) uchikomi osaekomi yang berpasangan tidak bisa dilakukan secara mandiri karena memerlukan bantuan dari pasangan; (3) uchikomi osaekomi yang berpasangan terlalu memakan tempat untuk berlatih sehingga memungkinkan jeda yang terlalu lama bagi pejudo pasangan lain untuk bergantian melakukan uchikomi.

Untuk itu diharapkan dengan menggunakan latihan variasi uchikomi bayangan (shadow) osaekomi dengan uchikomi berpasangan osaekomi dapat meningkatakan hasil osaekomi saat randori. Diharapkan pejudo menjadi tertarik dengan bentuk latihan ini, dan dapat mempengaruhi hasil osae komi saat randori. Dalam penelitian ini teknik yang akan dilatih dengan menggunakan teknik permainan bawah (katame waza) khususnya untuk teknik kuncian (osaekomi). Teknik yang dilatihkan adalah uchikomi bayangan (shadow) osaekomi dan uchikomi berpasangan osaekomi adalah 5 teknik yaitu, keza gatame, kata gatame, kami shio gatame, yoko shiho gatame, dan tate shio gatame, hal ini sesuai dengan hasil observasi dalam kejuaraan nasional serta kejuaraan daerah karena teknik inilah yang sering dipakai dalam pertandingan Judo.

Dari berbagai pengertian dan penjelasan yang telah dikemukakan di atas bahwa uchikomi bayangan (shadow) osaekomi dan uchikomi berpasangan osaekomi memiliki perbedaan dimana perbedaan tersebut bisa dilihat dari keunggulan dan kelemahan masing-masing metode. Perbedaan di antaranya yaitu: (1) uchikomi bayangan (shadow) osaekomi bisa dilakukan dengan mandiri sedangkan pada uchikomi berpasangan osaekomi harus dilakukan dengan berpasangan; (2) uchikomi bayangan (shadow) osaekomi akan mudah dilakukan pada atlet yang memiliki power lengan kuat sedangkan pada uchikomi berpasangan osaekomi akan mudah bagi pejudo yang memiliki power lengan yang lemah; (3) uchikomi bayangan (shadow) osaekomi hanya terfokus pada satu titik sedangkan pada uchikomi berpasangan osaekomi akan membiasakan pejudo untuk bergerak sesuai atau identik dengan pertandingan atau randori; (4) uchikomi bayangan (shadow) osaekomi tidak membutuhkan tempat yang luas sedangkan pada uchikomi berpasangan osaekomi membutuhkan tempat yang cukup luas.

Komponen biomotor power merupakan salah satu unsur yang penting dalam rangka pembinaan olahraga. Power adalah kesanggupan atau kemampuan dari tubuh manusia untuk melakukan penyesuaian untuk melakukan penyesuaian atau adaptasi terhadap beban fisik yang dihadapi tanpa menimbulkan kelelahan yang berlebihan, dan memiliki kapasitas cadangan untuk melakukan aktivitas berikutnya. Menurut Suharjana (2013, p.144) power (daya ledak) adalah hasil dari kekuatan dan kecepatan. Power sangat dibutuhkan dalam melakukan semua kegiatan olahraga karena dengan adanya power kita dapat melakukan suatu kegiatan olahraga dengan sangat mudah.

Berdasarkan teori di atas dalam penelitian ini komponen biomotor yang digunakan sebagai variabel atribut adalah power. Power digunakan dalam penelitian ini dikarenakan power merupakan salah satu faktor yang berpengaruh terhadap hasil osaekomi Judo yang baik. Menurut Sukadiyanto dalam Prayadi, (2013, p.66), power adalah hasil kali antara kekuatan dan kecepatan. Power adalah kesanggupan atau kemampuan dari tubuh manusia untuk melakukan penyesuaian untuk melakukan penyesuaian atau adaptasi terhadap beban fisik yang dihadapi tanpa menimbulkan kelelahan yang berlebihan, dan memiliki kapasitas cadangan untuk melakukan aktivitas berikutnya. Power adalah perpaduan antara kecepatan dan kekuatan. Power dapat pula disebut sebagai daya ledak otot. Power (daya ledak) adalah kemapuan seseorang untuk menggunakan kekuatan maksimum yang dikerahkan dalam waktu yang sependek-pendeknya. Daya ledak merupakan perpaduan antara kekuatan dan kecepatan kontraksi otot. Kemampuan daya ledak seseorang dapat dilihat dari kemampuannya melakukan gerakan dengan kuat secara eksplosif. Power sangat dibutuhkan dalam melakukan semua kegiatan olahraga karena dengan adanya power kita dapat melakukan suatu kegiatan olahraga dengan sangat mudah.

Judo is a full on fight players, grapple, thorw and try control their opponent, hopefully getting them to submit. Players need to repeat incredible bursts of pace they need power, strength, power lengan, endurance, skill and controlled aggression. (Aureilien, 2010, p.30) yang artinya judo adalah pertandingan penuh dimana pejudo bergulat, membanting dan mencoba mengendalikan lawan. Pejudo harus mengulangi kecepatan, dan membutuhkan power, kekuatan, fleksibilitas, daya tahan, keterampilan dan agresi yang dikontrol. 
Berdasarkan teori tersebut dalam penelitian ini komponen biomotor yang digunakan sebagai variabel atribut adalah power. Power digunakan dalam penelitian ini dikarenakan. Power merupakan salah satu faktor yang berpengaruh terhadap hasil osaekomi Judo yang baik.

\section{METODE}

Metode yang digunakan dalam penelitian ini adalah metode eksperimen. Sebagaimana dikemukakan oleh Surahmad (2003, p.149) sebagai berikut: Dalam arti kata yang luas bereksperimen adalah mengadakan kegiatan percobaan untuk melihat suatu hasil. Penelitian ini adalah penelitian eksperimen yang bertujuan untuk membandingkan dua perlakuan yang berbeda pada subjek penelitian. Metode penelitian yang digunakan dalam penelitian ini adalah menggunakan rancangan faktorial $2 \times 2$, yaitu suatu eksperimen faktorial yang menyangkut dua faktor. Masing-masing faktor terdiri dari dua buah taraf, dengan menggunakan tes awal (pre-test) dan tes akhir (post-test). Data penelitian ini disusun dalam kerangka desain penelitian dengan rancangan faktorial $2 \times 2$ seperti pada Tabel 1 .

Tabel 1. Rancangan ekperimen desain faktorial 2x2

\begin{tabular}{lll}
\hline \multicolumn{1}{c}{ Latihan Uchikomi } & \multicolumn{1}{c}{$\begin{array}{c}\text { Uchikomi bayangan (shadow) } \\
\text { Power lengan }\end{array}$} & Uchikomi berpasangan osaekomi \\
Pow & (A2)
\end{tabular}

Keterangan:

$\mathrm{A}_{1} \mathrm{~B}_{1}$ : Kelompok yang memiliki power lengan kuat dilatih mengunakan latihan uchikomi bayangan (shadow) osaekomi.

$\mathrm{A}_{2} \mathrm{~B}_{1}$ : Kelompok yang memiliki power lengan tinggi dilatih mengunakan latihan uchikomi berpasangan osaekomi.

$\mathrm{A}_{1} \mathrm{~B}_{2}$ : Kelompok yang memiliki power lengan lemah dilatih mengunakan latihan uchikomi bayangan (shadow) osaekomi.

$\mathrm{A}_{2} \mathrm{~B}_{2}$ : Kelompok yang memiliki power lengan lemah dilatih mengunakan latihan uchikomi berpasangan osaekomi.

Penelitian ini mengambil tempat di Dojo Klub Judo Sleman dan UKM Judo UNY pada saat pejudo Klub Judo Sleman dan UKM Judo UNY berlatih, dan waktunya setiap hari Senin, Selasa, Rabu, Kamis, Jumat dan Sabtu pukul 16.00-17.30 Wib, selama 8 minggu. Hal ini sesuai dengan pendapat Bompa \& Haff (2009, p.207) maksudnya adalah agar tubuh beradaptasi dengan beban latihan yang diterima.

Populasi adalah wilayah generalisasi yang terdiri atas objek atau subjek yang mempunyai kualitas dan karakteristik tertentu yang diterapkan oleh peneliti untuk dipelajari dan kemudian ditarik kesimpulan (Sugiyono, 2005, p.55). Sedangkan Sutrisno Hadi (2004, p.182) menyatakan bahwa populasi adalah seluruh penduduk yang dimaksud untuk diselidiki. Jumlah populasi dalam penelitian ini adalah Pejudo Klub Sleman dan UKM Judo UNY sebanyak 44 pejudo.

Sampel adalah sebagian dari jumlah karakteristik yang dimiliki oleh populasi (Sugiyono, 2005, p.56). Teknik pengambilan sample dalam penelitian adalah dengan menggunakan teknik probability sampling (Sugiyono, 2005, p.84) "Probability sampling adalah teknik pengambilan sample yang memberikan peluang yang sama bagi setiap unsur (anggota) populasi untuk dipilih menjadi anggota sampel. Karakteristik sampel yang diambil dalam penelitian ini adalah pejudo Klub Sleman dan UKM Judo UNY sebanyak 44 pejudo. Sampel berjenis kelamin laki-laki dengan tingkatan kyu 4-kyu 1, dan usia taruna yaitu usia 16-19 tahun.

Cara pengambilan sampel tersebut yaitu sebelum eksperimen dilaksanakan, populasi sebanyak 44 orang dilakukan tes dan pengukuran power lengan dengan menggunakan push up. Tes dilakukan di masing-masing klub. Tes ini digunakan untuk mengetahui skor awal yang menunjukkan power lengan. Setelah data power lengan terkumpul, langkah pertama dalam analisis adalah untuk mengidentifikasikan kelompok atas dan bawah dengan menggunakan skor tes keseluruhan. Sampel yang digunakan adalah bagian atas $27 \%$ dan bawah $27 \%$ dari skor keseluruhan setelah diurutkan dari yang tinggi ke yang rendah diranking menggunakan bagian atas $27 \%$ dan bawah $27 \%$ dari skor keseluruhan.

Langkah untuk menganalisis data tersebut adalah sebagai berikut: (1) mengatur tes dalam rangka menentukan skor tinggi dan skor rendah; (2) menentukan $27 \%$ skor tinggi dan $27 \%$ skor 
rendah dengan menempatkan dalam satu kelompok sama. Kelompok-kelompok ini disebut kelompok atas dan kelompok bawah, dengan demikian $27 \%$ kelompok atas dan $27 \%$ kelompok bawah dianggap yang terbaik untuk memaksimalkan perbedaan antara dua kelompok (Miller, 2002, p.68).

Pengelompokan dilakukan dengan cara data power lengan yang telah diperoleh dirangking terlebih dahulu (dibuat dari peringkat dari yang kuat ke yang lemah), sampel diambil dari pejudo yang memiliki power lengan kuat yaitu 27\% peringkat atas dan pejudo yang memiliki power lengan lemah yaitu $27 \%$ peringkat bawah dari seluruh data power lengan yang telah dirangking. Berdasarkan hal tersebut didapat 12 pejudo yang memiliki power lengan kuat dan 12 pejudo yang memiliki power lengan lemah, kemudian masing-masing dibagi menjadi dua kelompok dengan cara diundi (random), yaitu 12 pejudo mendapat metode uchikomi bayangan (shadow) osaekomi dan 12 pejudo mendapat metode uchikomi berpasangan osaekomi yang artinya dari dua kelompok tersebut menjadi empat kelompok sel.

Pembagian kelompok dengan cara ini akan lebih objektif bagi semua subjek penelitian. Hal ini didasarkan atas kesempatan yang sama bagi semua objek untuk masuk ke dalam tiap kelompok. Setelah terbagi menjadi empat kelompok, selanjutnya setiap kelompok power lengan kuat dan lemah melakukan pretest randori dengan melihat hasil osaekomi sebelum dilakukan eksperimen dengan pemberian perlakuan (treatment).

Variabel dalam penelitian ini adalah: 1 . Variabel bebas perlakuan yaitu latihan yang terdiri dari dua, antara lain: (1) Latihan uchikomi dengan uchikomi bayangan (shadow) osaekomi individu; (2) Latihan uchikomi dengan uchikomi berpasangan (osaekomi). 2. Variabel bebas atribut dalam penelitian ini, terdiri: (1) Power lengan kuat; (2) Power lengan lemah. Variabel terikat penelitian ini adalah hasil osaekomi saat randori.

Teknik pengumpulan data dalam penelitian ini dengan menggunakan: 1. Teknik pengumpulan data power diperoleh dengan tes menggunakan push up dengan menepuk kedua tangan selama 30 detik. Data power dapat digunakan untuk mengelompokkan (1) sampel yang memiliki power lengan kuat; (2) sampel yang memiliki power lengan lemah. 2. Data hasil osaekomi. Teknik pengumpulan data tentang hasil osaekomi diperoleh dengan menggunakan tes praktik masing-masing atlit dirandorikan selama 4 menit lalu dinilai oleh wasit judo dengan 4 tingkatan nilai yaitu koka dengan nilai 1 (tori mampu mengunci uke selama 15 detik). Yuko dengan nilai 2 (tori mampu mengunci uke selama 20 detik). Waza-ari dengan nilai 3 (tori mampu mengunci uke selama 25 detik). Ippon dengan nilai 4 (tori mampu mengunci uke selama 30 detik). Randori yang dilaksanakan adalah randori permainan bawah dengan kedua pejudo saling berhadapan dan melakukan kumikata dengan satu lutut menyentuh matras dan satu tungkai kaki ditekuk membentuk sudut $90^{\circ}$.

Validitas adalah sejauh mana ketepatan dan kecermatan suatu alat ukur dalam melakukan fungsi ukurannya atau memberikan hasil ukur yang sesuai dengan maksud dilakukannya pengukuran tersebut. Menurut Muhidin (2007, p.30) instrumen dinyatakan memiliki validitas apabila instrumen tersebut telah dirancang dengan baik dan mengikuti teori dan ketentuan yang ada. Validitas hasil osaekomi sebesar 0,918 dan validitas untuk power lengan sebesar 0,836. Reliabilitas adalah sejauh mana hasil pengukuran dapat menunjukkan hasil relatif sama dalam beberapa kali pengukuran terhadap kelompok subjek yang sama (Muhidin, 2007, p.37). Reliabilitas untuk hasil osaekomi sebesar 0,957 dan power lengan sebesar 0,910.

Teknik analisis data yang digunakan dalam penelitian ini dengan menggunakan SPSS 20 yaitu Analisis Varian (ANAVA) dua jalur pada taraf signifikansi $\alpha=0,05$. Untuk memenuhi asumsi ANAVA maka dilakukan uji normalitas dengan Kolmogorov Smirnow dan homogenitas dengan uji Levene Test. Untuk menguji hipotesis dilakukan dengan menggunakan ANAVA dua jalur dan apabila terbukti terdapat interaksi maka akan dilakukan uji lanjutan yaitu uji pairwise comparisons yaitu dengan menggunakan program software SPSS version 20.0 for windows dengan taraf signifikansi $5 \%$ atau 0,05 .

Program latihan uchikomi bayangan (shadow) osaekomi dengan uchikomi osaekomi berpasangan, dan power terhadap hasil osaekomi judo setelah dilakukan pretest. Frekuensi 3x/minggu dilaksanakan selama 8 minggu, setelah itu dilakukan posttest. Durasi latihan selama 5 menit hal ini sesuai dengan kriteria pertandingan judo yang mana memiliki durasi untuk senior 4 menit dan 3 menit untuk junior. Lamanya latihan sebanyak 60-90 menit, repetisi latihan mengacu pada sistem beban berlebih serta istirahat atau recovery selama 2-5 menit. 
JORPRES (Jurnal Olahraga Prestasi), 15 (1), 2019 - 8

Hoesana Dian Dewi Andalas, Sugeng Purwanto

\section{HASIL DAN PEMBAHASAN}

\section{Hasil}

Hasil yang diperoleh dari penelitian berupa data yang merupakan gambaran umum tentang masing-masing variabel yang terkait dalam penelitian. Melalui gambaran umum ini akan nampak kondisi awal dan kondisi akhir dari setiap variabel yang diteliti dengan melakukan pengolahan data setelah data berhasil dikumpulkan selama periode latihan yang telah ditentukan.

Tabel 2. Deskripsi data hasil osaekomi judo tiap kelompok berdasarkan penggunaan metode latihan uchikomi osaekomi shadow dan uchikomi osaekomi berpasangan dan power lengan.

\begin{tabular}{llllll}
\hline \multicolumn{1}{c}{ Perlakuan } & Tingkat power lengan & Statistik & Hasil Tes awal & Hasil Tes Akhir & Peningkatan \\
\hline Metode Latihan & Kuat & Jumlah & 83 & 144 & 61 \\
Uchikomi osaekomi & & Rerata & 13,8 & 24 & 10,1 \\
shadow & & SD & 2,4 & 2 & \\
& Lemah & Jumlah & 63 & 100 & 22 \\
& & Rerata & 10,5 & 16.6 & 3,6 \\
Metode Latihan & \multirow{2}{*}{ Kuat } & SD & 3,31 & 2,71 & 48 \\
Uchikomi osaekomi & & Jumlah & 85 & 133 & 8 \\
berpasangan & & Rerata & 14,1 & 22,1 & \\
& Lemah & SD & 2,88 & 1,83 & 71 \\
& & Jumlah & 61 & 132 & 11,8 \\
& & Rerata & 10,1 & 22 & \\
\hline
\end{tabular}

Masing-masing sel (kelompok perlakuan) memiliki peningkatan hasil osaekomi yang berbeda. Nilai rata-rata peningkatan hasil osaekomi masing-masing sel (kelompok perlakuan) dapat dilihat pada Tabel 3.

Tabel 3. Nilai peningkatan hasil osaekomi masing-masing sel (kelompok perlakuan)

\begin{tabular}{cll}
\hline No. & Kelompok perlakuan $(\mathrm{sel})$ & Nilai rerata peningkatan hasil osaekomi judo \\
\hline 1. & A1B1 $\left(\mathrm{KP}_{1}\right)$ & 10,1 \\
2. & $\mathrm{A} 1 \mathrm{~B} 2\left(\mathrm{KP}_{2}\right)$ & 3,6 \\
3. & $\mathrm{~A} 2 \mathrm{~B} 1\left(\mathrm{KP}_{2}\right)$ & 8 \\
4. & $\mathrm{A} 2 \mathrm{~B} 2\left(\mathrm{KP}_{2}\right)$ & 11,8 \\
\hline
\end{tabular}

\section{Analisis Data}

Uji Normalitas

Tabel 4. Rangkuman hasil osaekomi tes awal uji normalitas data One-Sample Kolmogorov-Smimov Test

\begin{tabular}{|c|c|c|c|c|c|}
\hline & & $\begin{array}{l}\text { Kelompok } \\
\text { Power Lengan } \\
\text { kuat Dengan } \\
\text { Uchikomi } \\
\text { shadow } \\
\text { osaekomi }\end{array}$ & $\begin{array}{l}\text { Kelompok yang } \\
\text { memiliki power } \\
\text { lengan kuat dilatih } \\
\text { mengunakan } \\
\text { Uchikomi osaekomi } \\
\text { berpasangan }\end{array}$ & $\begin{array}{l}\text { Kelompok yang } \\
\text { memiliki power } \\
\text { lengan lemah } \\
\text { dilatih } \\
\text { mengunakan } \\
\text { Uchikomi shadow } \\
\text { osaekomi }\end{array}$ & $\begin{array}{l}\text { Kelompok yang } \\
\text { memiliki power } \\
\text { lengan lemah } \\
\text { dilatih mengunakan } \\
\text { Uchikomi osaekomi } \\
\text { berpasangan }\end{array}$ \\
\hline \multicolumn{2}{|l|}{$\mathrm{N}$} & 6 & 6 & 6 & 6 \\
\hline \multirow{2}{*}{$\begin{array}{l}\text { Normal } \\
\text { Parameters }^{\mathrm{a}, \mathrm{b}}\end{array}$} & Mean & 13,8333 & 105.000 & 141.667 & 101.667 \\
\hline & $\begin{array}{l}\text { Std, } \\
\text { Deviation }\end{array}$ & 2,40139 & 288.097 & 331.160 & 248.328 \\
\hline \multirow{3}{*}{$\begin{array}{l}\text { Most Extreme } \\
\text { Differences }\end{array}$} & Absolute & 0,214 & 0,199 & 0,164 & 0,193 \\
\hline & Positive & 0,214 & 0,199 & 0,164 & 0,193 \\
\hline & Negative & $-0,194$ & $-0,199$ & $-0,147$ & $-0,153$ \\
\hline \multicolumn{2}{|c|}{ Kolmogorov-Smirnov Z } & 0,525 & 0,487 & 0,401 & 0,474 \\
\hline \multicolumn{2}{|c|}{ Asymp, Sig, (2-tailed) } & 0,946 & 0,972 & 0,997 & 0,978 \\
\hline
\end{tabular}


JORPRES (Jurnal Olahraga Prestasi), 15 (1), 2019 - 9

Hoesana Dian Dewi Andalas, Sugeng Purwanto normal.

Pada tabel 4 didapat semua hasil kelompok sig $\mathrm{p}>0,05$ yang berarti bahwa data berdistribusi

Uji homogenitas tes awal dan akhir osaekomi

Tabel 5: Test of Homogeneity of Variances Hasil Osaekomi Awal

\begin{tabular}{cccc}
\hline Levene Statistic & df1 & df2 & Sig. \\
\hline, 010 & 1 & 22 &, 922 \\
\hline \multirow{2}{*}{ Tabel 6: Test of Homogeneity of Variances Hasil Osaekomi Akhir } & \\
\hline Levene Statistic & df1 & df2 & Sig. \\
\hline 23,067 & 1 & 22 &, 885 \\
\hline
\end{tabular}

Berdasarkan tabel didapat hasil uji Levene Test $\mathrm{p}>0,05$ yang berarti bahwa data bersifat homogen.

Uji hipotesis

Hasil uji hipotesis dengan SPSS 20.0 dapat dilihat sebagai berikut:

Tabel 7: Hasil osaekomi (Tabel Estimates) Uji hipotesis 1

\begin{tabular}{lcclc}
\hline Eksperiment & Mean & Std, Error & $95 \%$ Confidence Interval & \\
\hline Uchikomi shadow osaekomi & & & Lower Bound & Upper Bound \\
Uchikomi osaekomi berpasangan & 23.083 & 0,631 & 21.766 & 24.400 \\
& 18.083 & 0,631 & 16.766 & 19.400 \\
\hline
\end{tabular}

Tabel 8: Univariate Tests Uji hipotesis 1

\begin{tabular}{llllll}
\hline & Sum of Squares & Df & Mean Square & F & Sig, \\
\hline Contrast & 150,000 & 1 & 150,000 & 31,359 & 0 \\
Error & 95,667 & 20 & 4,783 & & \\
\hline
\end{tabular}

The $\mathrm{F}$ tests the effect of Eksperiment, This test is based on the linearly independent pairwise comparisons among the estimated marginal means,

Pada taraf sig diperoleh sebesar $0,000<0,05$ hal ini berarti terdapat perbedaan pengaruh yang signifikan antara metode uchikomi osekomi shadow dan uchikomi osaekomi berpasangan terhadap hasil osaekomi Judo yang baik. Hipotesis yang dinyatakan bahwa: Ada perbedaan pengaruh antara metode uchikomi osaekomi shadow dan uchikomi osaekomi berpasangan terhadap hasil osaekomi pada UKM Judo Universitas Negeri Yogyakarta dan klub Judo Sleman. Berdasarkan dari nilai signifikansi Univariate Tests sebesar 0,00 < 0,05 yang berarti bahwa lebih kecil dari taraf signifikan. Dengan demikian hipotesis 1 yang menyatakan ada perbedaan pengaruh antara metode uchikomi osaekomi shadow dan uchikomi osaekomi berpasangan terhadap hasil osaekomi Judo yang baik, diterima. Dari analisis lanjutan diperoleh bahwa ternyata metode latihan uchikomi osaekomi berpasangan memiliki peningkatan yang lebih baik dari pada metode latihan uchikomi osaekomi shadow. Dengan demikian metode latihan uchikomi osaekomi berpasangan lebih baik daripada metode latihan uchikomi osaekomi shadow pada masa sebelum retensi, sebagai hasil fase latihan.

Tabel 9. Hasil power lengan Tabel Estimates Uji hipotesis 2

\begin{tabular}{lccccc}
\hline \multirow{2}{*}{ Power } & \multirow{2}{*}{ Mean } & \multirow{2}{*}{ Std. Error } & \multicolumn{2}{c}{ 95\% Confidence Interval } \\
\cline { 4 - 6 } & & & \multicolumn{2}{c}{ Lower Bound } & Upper Bound \\
\hline Kuat & 19,083 &, 631 & 17,766 & 20,400 \\
Lemah & 22,083 &, 631 & 20,766 & 23,400 \\
\hline
\end{tabular}

Tabel 10. Univariates Test Uji hipotesis 2

\begin{tabular}{llllll}
\hline Contrast & Sum of Squares & Df & Mean Square & F & Sig. \\
\cline { 2 - 5 } & 54,000 & 1 & 54,000 & 11,289 &, 003 \\
\hline Error & 95,667 & 20 & 4,783 & & \\
\hline
\end{tabular}

The F tests the effect of Power. This test is based on the linearly independent pairwise comparisons among the estimated marginal means. 
Pada taraf sig diperoleh sebesar 0,03 $<0,05$ hal ini berarti terdapat perbedaan hasil osaekomi Judo yang signifikan antara pejudo yang memiliki power lengan kuat dan power lengan lemah. Hipotesis yang dinyatakan bahwa: Ada perbedaan peningkatan hasil osaekomi antara pejudo yang memiliki power lengan kuat dan lemah. Berdasarkan dari nilai signifikansi Univariate Tests sebesar $0,03<0,05$ yang berarti bahwa lebih kecil dari taraf signifikan. Dengan demikian hipotesis 2 yang menyatakan ada perbedaan peningkatan hasil osaekomi Judo yang baik antara atlet yang memiliki power lengan kuat dan power lengan lemah, diterima. Dari analisis lanjutan diperoleh bahwa ternyata power lengan lemah memiliki peningkatan yang lebih baik daripadapower lengan kuat. Dengan demikian metode latihan uchikomi osaekomi berpasangan lebih baik dari pada metode latihan uchikomi osaekomi shadow pada masa sebelum retensi, sebagai hasil fase latihan.

Tabel 11. Hasil interaksi metode latihan uchikomi osaekomi dan power lengan terhadap hasil osaekomi (Uji hipotesis 3)

\begin{tabular}{llllll}
\hline \multicolumn{7}{c}{ Tests of Between-Subjects Effects Dependent Variable: Hasil Osaekomi } \\
\hline Source & Type III Sum of Squares & Df & Mean Square & F & Sig, \\
\hline Corrected Model & $344,167 \mathrm{a}$ & 3 & 114,722 & 23,984 & 0 \\
Intercept & $10,168.167$ & 1 & $10,168,167$ & $2,125,749$ & 0 \\
Inter & 344,167 & 3 & 114,722 & 23,984 & 0 \\
Error & 95,667 & 20 & 4,783 & & \\
Total & $10,608,000$ & 24 & & & \\
Corrected Total & 439,833 & 23 & & & \\
\hline
\end{tabular}

a. R Squared $=, 782$ (Adjusted R Squared $=, 750)$

Pada taraf sig diperoleh sebesar $0,000<0,05$ hal ini berarti terdapat interaksi yang signifikan antara metode uchikomi dan power lengan terhadap hasil osaekomi Judo yang baik. Hipotesis yang dinyatakan bahwa: Ada interaksi antara metode uchikomi dan power lengan terhadap hasil osaekomi Judo yang baik pada UKM Judo Universitas Negeri Yogyakarta dan klub Judo Sleman. Berdasarkan hasil perhitungan Tests of Between-Subjects Effects didapat bahwa taraf a. R Squared =,782 (Adjusted R Squared = ,750)

Signifikansi sebesar 0,00<0,05, hal ini menunjukkan bahwa tingkat signifikansi 5\% ada pengaruh bersama antara metode latihan uchikomi dan power lengan terhadap hasil osaekomi Judo. Dengan demikian hipotesis 3 yang menyatakan bahwa Ada interaksi antara metode uchikomi dan power lengan terhadap hasil osaekomi Judo yang baik pada UKM Judo Universitas Negeri Yogyakarta dan klub Judo Sleman, diterima.

Setelah teruji terdapat interaksi antara metode uchikomi dan power lengan terhadap hasil osaekomi Judo yang baik maka perlu dilakukan uji lanjut dengan menggunakan Pairwise Comparisons. Berikut hasil uji lanjut dapat dilihat pada Tabel 10.

Tabel 12. Pairwise Comparisons Dependent Variable: Hasil Osaekomi

\begin{tabular}{|c|c|c|c|c|c|c|}
\hline \multirow[t]{2}{*}{ (I) Interaksi } & \multirow[t]{2}{*}{ (J) Interaksi } & \multirow{2}{*}{$\begin{array}{l}\text { Mean Difference (I- } \\
\text { J) }\end{array}$} & \multirow[t]{2}{*}{ Std. Error } & \multirow[t]{2}{*}{ Sig. ${ }^{\text {b }}$} & \multicolumn{2}{|c|}{$\begin{array}{l}\text { 95\% Confidence Interval for } \\
\text { Difference }\end{array}$} \\
\hline & & & & & Lower Bound & Upper Bound \\
\hline \multirow{5}{*}{ A1B1 } & A1B2 & 1,833 & 1,263 & ,162 &,- 801 & 4,467 \\
\hline & A2B1 & $9,833^{*}$ & 1,263 & ,000 & 7,199 & 12,467 \\
\hline & A2B2 & 2,000 & 1,263 & , 129 &,- 634 & 4,634 \\
\hline & A1B1 & $-1,833$ & 1,263 & , 162 & $-4,467$ &, 801 \\
\hline & A2B 1 & $8,000^{*}$ & 1,263 & ,000 & 5,366 & 10,634 \\
\hline \multirow[t]{3}{*}{ A1B2 } & A2B2 & ,167 & 1,263 & ,896 & $-2,467$ & 2,801 \\
\hline & A1B1 & $-9,833^{*}$ & 1,263 & 000 & $-12,467$ & $-7,199$ \\
\hline & A1B2 & $-8,000^{*}$ & 1,263 & ,000 & $-10,634$ & $-5,366$ \\
\hline \multirow[t]{3}{*}{$\mathrm{A} 2 \mathrm{~B} 1$} & A2B2 & $-7,833^{*}$ & 1,263 & ,000 & $-10,467$ & $-5,199$ \\
\hline & A1B1 & $-2,000$ & 1,263 & , 129 & $-4,634$ & ,634 \\
\hline & A1B2 &,- 167 & 1,263 & 896 & $-2,801$ & 2,467 \\
\hline A2B2 & A2B 1 & $7,833^{*}$ & 1,263 &, 000 & 5,199 & 10,467 \\
\hline
\end{tabular}

Based on estimated marginal means

*. The mean difference is significant at the .05 level.

b. Adjustment for multiple comparisons: Least Significant Difference (equivalent to no adjustment). 


\section{JORPRES (Jurnal Olahraga Prestasi), 15 (1), 2019 - 11}

Hoesana Dian Dewi Andalas, Sugeng Purwanto

Berdasarkan tabel hasil perhitungan Pairwise Comparisons pada tanda asterisk (*) menunjukkan bahwa pasangan-pasangan yang memiliki interaksi atau pasangan yang berbeda secara nyata (signifikan). adalah: (1) pasangan antara A1B1 dengan A1B2. (2) pasangan antara A1B1 dengan A2B1. (3) A1B2 dengan A2B1. (4) pasangan antara A1B2 dengan A2B2.

\section{Pembahasan}

Berdasarkan pengujian hipotesis pertama ternyata ada perbedaan pengaruh yang nyata antara kelompok pejudo yang mendapatkan metode uchikomi osaekomi shadow yang diterapkan pada UKM Judo UNY dan uchikomi osaekomi berpasangan yang diterapkan di klub Judo Sleman Yogyakarta. Pada kelompok pejudo yang dilatih dengan uchikomi osaekomi berpasangan mempunyai peningkatan hasil osaekomi Judo lebih baik jika dibandingkan dengan pejudo yang diberikan uchikomi osaekomi shadow. Dari hasil yang didapat, pada kelompok pejudo yang dilatih dengan uchikomi osaekomi berpasangan mempunyai peningkatan hasil osaekomi Judo lebih baik dapat dilihat dari nilai rerata peningkatan hasil peningkatan osaekomi yaitu sebesar 8,00 dan 11,8, sedangkan pada kelompok pejudo yang diberikan uchikomi osaekomi shadow mempunyai nilai rerata peningkatan hasil peningkatan osaekomi yaitu sebesar 10,1 dan 3,6.

Berdasarkan pengujian hipotesis kedua ternyata ada perbedaan pengaruh yang nyata antara kelompok pejudo yang memiliki power lengan kuat dan pejudo yang memiliki power lengan lemah. Dasil penelitian bahwa power lengan kuat lebih baik hasilnya jika dibandingkan dengan power lengan lemah, akan tetapi jika ditelusuri pada setiap kelompok bahwa power lengan lemah mengalami hasil yang baik ketika diberikan treatment uchikomi osaekomi berpasangan, karena didapat rerata sebesar 22,083, sedangkan pada kelompok power lengan kuat yang diberi treatment uchikomi osaekomi berpasangan didapat rerata sebesar 19,083. Mengapa kelompok dengan power lengan lemah mengalami hasil yang baik ketika diberikan treatment uchikomi osaekomi berpasangan, hal ini dikarenakan saat melakukan latihan uchikomi osaekomi berpasangan pejudo dengan power lengan lemah juga berlatih power sehingga lebih membantu dan memudahkan atlet dalam melakukan uchikomi selain itu uchikomi osaekomi berpasangan juga lebih indentik dengan suasana pertandingan, jadi meskipun pejudo hanya memiliki power lengan lemah, hasil dalam penelitian ini akan tetap mendapatkan solusi sehingga semua pejudo yang memiliki tingkatan power lengan baik kuat atau lemah bisa meraih prestasi.

Berdasarkan pengujian hipotesis ketiga dikemukankan pada hasil penelitian di atas bahwa terdapat interaksi yang berarti antara metode uchikomi dan power lengan terhadap hasil osaekomi Judo. Dari tabel yang disajikan bentuk interaksi nampak bahwa faktor-faktor utama penelitian dalam bentuk dua faktor menunjukan interaksi yang signifikan. Dalam hasil penelitian ini interaksi yang memiliki arti bahwa setiap sel atau kelompok terdapat perbedaan pengaruh setiap kelompok yang dipasang-pasangkan.

Berdasarkan hasil penelitian yang didapat, (1) ternyata pejudo yang memiliki power lengan lemah dilatih dengan uchikomi osaekomi berpasangan mengalami peningkatan yang lebih besar, urutan ke dua (2) pejudo yang memiliki power lengan kuat dilatih dengan uchikomi osaekomi shadow urutan ke tiga (3) pejudo yang memiliki power lengan kuat dengan uchikomi osaekomi berpasangan, dan yang ke empat (4) pejudo yang memiliki power lengan lemah uchikomi osaekomi shadow Keefektifan yang diterapkan untuk meningkatkan hasil osaekomi pejudo tersebut, dipengaruhi oleh kuat lemahnya power lengan yang dimiliki pejudo.

Dari beberapa pembahasan di atas untuk mengoptimalkan teknik osaekomi apabila didapat pejudo tersebut memiliki power lengan lemah maka pejudo tersebut lebih cocok dilatih dengan metode uchikomi osaekomi berpasangan karena dari hasil penelitian didapat pejudo yang memiliki power lengan lemah dilatih dengan metode metode uchikomi osaekomi berpasangan memiliki kenaikan peningkatan yang lebih tinggi yaitu 11,8, dan pejudo yang memiliki power lengan kuat lebih cocok dilatih dengan uchikomi osaekomi shadow, karena dari hasil penelitian didapat pejudo yang memiliki power lengan kuat dilatih dengan metode metode uchikomi osaekomi osaekomi memiliki kenaikan peningkatan sebesar 10,1. Mengapa uchikomi osaekomi berpasangan lebih cocok untuk pejudo yang memiliki power lengan lemah? Hal ini dikarenakan pejudo yang memiliki power lengan lemah akan lebih terbantu, karena saat berlatih uchikomi osaekomi berpasangan pejudo juga berlatih power, sehingga pejudo akan terbantu untuk melakukan uchikomi, selain itu uchikomi osaekomi berpasangan juga dalam pelaksanaannya lebih identik dengan suasana atau keadaan dalam bertanding, sedangkan 
bagi pejudo yang memiliki power lengan kuat lebih cocok dengan metode uchikomi osaekomi shadow, mengapa? Hal ini dikarenakan sifat dari uchikomi osaekomi shadow pejudo dapt membayangkan timing yang tepat sehingga bagi pejudo yang memiliki power lengan kuat akan mudah melakukannya jika di bandingkan bagi pejudo yang memiliki power lengan lemah.

\section{SIMPULAN}

Berdasarkan hasil penelitian dan hasil analisis data yang telah dilakukan, diperoleh simpulan sebagai berikut: Pertama ada perbedaan pengaruh yang signifikan antara metode latihan uchikomi dengan osaekomi bayangan (shadow) dan latihan uchikomi osaekomi berpasangan terhadap hasil osaekomi saat randori pada pejudo. Pada metode latihan uchikomi osaekomi berpasangan terhadap hasil osaekomi memiliki peningkatan yang lebih baik dibandingkan metode uchikomi dengan osaekomi bayangan (shadow). Kedua ada perbedaan yang signifikan antara pejudo yang memiliki power lengan kuat dan power lengan lemah terhadap peningkatan hasil osaekomi saat randori pada pejudo. Pada pejudo yang memiliki power lengan kuat terhadap hasil osaekomi memiliki peningkatan yang lebih baik dibandingkan pejudo yang memiliki power lengan lemah. Ketiga ada interaksi antara metode uchikomi dan power lengan terhadap hasil osaekomi saat randori pada pejudo. Interaksinya dengan adanya peningkatan hasil osaekomi yang lebih baik antara metode uchikomi dan power lengan, yaitu pada kelompok yang dilatihkan metode latihan uchikomi osaekomi berpasangan dengan power lengan lemah memiliki peningkatan hasil osaekomi lebih baik dibandingkan pada kelompok yang dilatihkan metode latihan uchikomi osaekomi berpasangan dengan power lengan kuat, sedangkan pada kelompok yang dilatihkan dengan metode latihan uchikomi osaekomi bayangan (shadow) dengan power lengan kuat memiliki peningkatan hasil osaekomi lebih baik dibandingkan pada kelompok yang dilatihkan metode latihan uchikomi osaekomi bayangan (shadow) dengan power lengan lemah.

\section{DAFTAR PUSTAKA}

Bompa, T. (2009). Theory and metodology of training. Iowa: Kendall Hunt Publishing Company.

Broussal, A. (2010). Judo at international level is amazing it's one of the most competitive sports in the world. British: The British Olympic Team.

David K. M. (2002). Measurement by the physical educator why and how. Amerika: Mcgraw-Hill Companies.

Detanico, D, \& Santos. S. G. (2012). Especific evaluation in judo: a review of methods. Journal of kinanthropomentry and human performance, 14(6).

Fadil, A. (2012). Pengaruh perbedaan sudut tolakan terhadap nilai power tungkai. Eprints.uny.ac.id. (diunduh tanggal 12 Februari 2015).

Franchini, E. (2015). Specificity of performance adaptations to a periodized judo training program. Journal of Science \& Sports, Volume 8, Issue 2. Pages 67-72

Franchini, E. B., Ciro J. Fukuda., et al. (2014). The physiology of judo-specific training modalities. Journal of Strength \& Conditioning Research, Volume 28 - Issue 5 - p 1474-1481.

Ghazali, A., Mansur, M., Widanita, N., Guntur, G., Putra, F., \& Fajaruddin, S. (2019). Developing pilates training model for decreasing the body fat ratio among overweight women. ACTIVE: Journal of Physical Education, Sport, Health and Recreation, 8(1), 9-17. doi https://doi.org/10.15294/active.v8i1.27908

Hadi, S. (2002). Methodologi research. Yogyakarta: Andi Offside.

Imamura R. T, Hreljac A, Escamilla R. F, at al. (2006). A three-dimensional analysis of the center of mass for three different judo throwing techniques. USA: California State University Sacramento.

Irianto, D. P. (2002). Diktat dasar kepelatihan olahraga. Yogyakarya: Universitas Negeri Yogyakarta.

Irianto, D. P. (2004). Panduan latihan kebugaran (yang efektif dan aman). Yogyakarta: Lukman Offset. Fox E. L. (1984). Sport physiology, second. 


\section{JORPRES (Jurnal Olahraga Prestasi), 15 (1), 2019 - 13}

Hoesana Dian Dewi Andalas, Sugeng Purwanto

Noors, A. M. (2000). Dasar-dasar judo. Jakarta: PT. Dian Rakyat.

Prayadi, H., \& Rachman, H. (2013). Pengaruh metode latihan dan power lengan terhadap kemampuan smash bulutangkis. Jurnal Keolahragaan, 1(1), 63-71. doi:https://doi.org/10.21831/jk.v1i1.2346

Rahyubi, H. (2012). Teori-teori belajar dan aplikasi pembelajaran motoric diskripsi dan tinjauan kritis. Bandung: Nusa Media.

Sugiyono. (2005). Metode penelitian kuantitafif, kualitatif, dan R\&D. Bandung: CV Alfabeta.

Suharjana. (2013). Kebugaran jasmani. Yogyakarta: Jogja Global Media.

Sukadiyanto. (2002). Teori dan metodologi melatih fisik petenis. Yogyakarta: Fakultas Ilmu Keolahragaan UNY.

Surachmad, W. (2003). Pengantar interaksi mengajar, belajar, dasar dan teknik metodologi pengajaran. Bandung: Tarsito.

Syah, M. (2003). Psikologi pendidikan dengan pendekatan baru. Bandung: Remaja Rosdakarya.

Yudiana, Y. (2009). Teori dan metode latihan. Jurnal.upi.edu. (diunduh 25 Juli 2014). 